\title{
The Biological Activity of Monarda didyma L. Essential Oil and Its Effect as a Diet Supplement in Mice and Broiler Chicken
}

\author{
Héloïse Côté ${ }^{1,2}$, André Pichette ${ }^{1,2}$, Alexis St-Gelais ${ }^{3}$ (D) and Jean Legault ${ }^{1,2, *}$ \\ 1 Laboratoire d'Analyse et de Séparation des Essences Végétales, Université du Québec à Chicoutimi, \\ 555 boulevard de l'Université, Chicoutimi, QC G7H 2B1, Canada; heloise.cote@uqac.ca (H.C.); \\ Andre_Pichette@uqac.ca (A.P.) \\ 2 Centre de Recherche sur la Boréalie (CREB), Département des Sciences Fondamentales, \\ Université du Québec à Chicoutimi, 555 boulevard de l'Université, Chicoutimi, QC G7H 2B1, Canada \\ 3 Laboratoire PhytoChemia Inc., 628 Boul. du Saguenay Ouest, Saguenay, QC G7J 1H4, Canada; \\ a.st-gelais@phytochemia.com \\ * Correspondence: Jean_Legault@uqac.ca
}

check for updates

Citation: Côté, H.; Pichette, A.; St-Gelais, A.; Legault, J. The Biological Activity of Monarda didyma L. Essential Oil and Its Effect as a Diet Supplement in Mice and Broiler Chicken. Molecules 2021, 26, 3368. https://doi.org/10.3390/molecules 26113368

Academic Editor:

Francesca Mancianti

Received: 9 March 2021

Accepted: 13 May 2021

Published: 2 June 2021

Publisher's Note: MDPI stays neutral with regard to jurisdictional claims in published maps and institutional affiliations.

Copyright: (c) 2021 by the authors. Licensee MDPI, Basel, Switzerland. This article is an open access article distributed under the terms and conditions of the Creative Commons Attribution (CC BY) license (https:/ / creativecommons.org/licenses/by/ $4.0 /)$.

\begin{abstract}
The use of growth-promoting antibiotics in livestock faces increasing scrutiny and opposition due to concerns about the increased occurrence of antibiotic-resistant bacteria. Alternative solutions are being sought, and plants of Lamiaceae may provide an alternative to synthetic antibiotics in animal nutrition. In this study, we extracted essential oil from Monarda didyma, a member of the Lamiaceae family. We examined the chemical composition of the essential oil and then evaluated the antibacterial, antioxidant, and anti-inflammatory activities of $M$. didyma essential oil and its main compounds in vitro. We then evaluated the effectiveness of $M$. didyma essential oil in regard to growth performance, feed efficiency, and mortality in both mice and broilers. Carvacrol (49.03\%) was the dominant compound in the essential oil extracts. M. didyma essential oil demonstrated antibacterial properties against Escherichia coli $\left(\mathrm{MIC}=87 \mu \mathrm{g} \cdot \mathrm{mL}^{-1}\right)$, Staphylococcus aureus (MIC $\left.=47 \mu \mathrm{g} \cdot \mathrm{mL}^{-1}\right)$, and Clostridium perfringens ( $\mathrm{MIC}=35 \mu \mathrm{g} \cdot \mathrm{mL}^{-1}$ ). Supplementing the diet of mice with essential oil at a concentration of $0.1 \%$ significantly increased body weight $(+5.4 \%)$ and feed efficiency $(+18.85 \%)$. In broilers, $M$. didyma essential oil significantly improved body weight gain (2.64\%). Our results suggest that adding $M$. didyma essential oil to the diet of broilers offers a potential substitute for antibiotic growth promoters.
\end{abstract}

Keywords: Monarda didyma; antibacterial activity; essential oil; broiler; mouse

\section{Introduction}

Antibiotic growth promoters (AGPs) have long been used in animal nutrition to reduce mortality and increase the feed conversion ratio and body weight gain, especially for broilers and swine [1-5]. The AGPs given for animal nutrition and agents used for treatment against bacterial infection in humans often belong to the same classes of antibiotics; this heightens the risk of bacteria developing resistance to antibiotics [6]. The enhanced resistance and the issues surrounding the excessive use of in-feed AGPs have led researchers to search out more natural alternatives. In Europe, AGPs have been prohibited for use in animal nutrition since 2006 [3].

In Canada, poultry production involves more than 2600 regulated chicken producers who have access to several AGPs approved as feed additives for poultry [6]. The use of AGPs in Canada is still permitted; however, since 2014, producers have been forced to remove those antibiotics considered as the most important for human health. This important restriction is part of a strategy involving the responsible use of antibiotics by producers and the search for new alternatives. A similar strategy for controlling antibiotic resistance is used in the United States, although there are some differences in regard to their classification of antibiotics compared to the Canadian and World Health Organization (WHO) classifications. 
The drive for alternatives to standard AGPs involves finding compounds that ensure poultry health and decrease bacterial resistance while maintaining producer profitability. Public pressure and concerns about food and environmental safety have led to an active search for alternative approaches that could eliminate or decrease the use of antibiotics, such as the use of essential oil, probiotics, prebiotics, and acidifiers in diets. As natural and multi-active agents, plant extracts and plant-derived products offer an interesting potential as substitutes for synthetic antibiotics and inorganic chemicals. Essential oil has some advantages over the others, by (1) improving growth performance and nutrient digestibility through antioxidative and anti-inflammatory activity, and (2) improving intestinal and general health of the broiler via antibacterial and coccidiostatic effects [7-10]. Both the food industry and animal producers have increased their interest in the use of essential oils (EOs, volatile plant compounds). The positive effects of EO in the digestive tract of animals include the stabilizing of gut microbiota; this benefit could lead to further practices that improve intestinal health, digestion, and growth performance of livestock [6].

Some EOs have already been investigated in animal nutrition studies [11-16]. Plants from the Lamiaceae family are particularly promising [15-19]; for example, Denli et al. [20] added thyme essential oil to the diet of quail, resulting in significantly increased body weight gain and better feed efficiency relative to a control group. A member of the Lamiaceae, Monarda didyma L., has been used for millennia by indigenous people in North America to treat colic, flatulence, colds, and flu. This plant is also used in infusions for intestinal and stomach problems [21], and is particularly useful for treating digestive disorders [22].

At present, there are no studies on the bioactivity of M. didyma EO. Nonetheless, compounds such as thymol and carvacrol—often present in the EO of Monarda species [22] have marked antibacterial and anti-inflammatory activities [23-25]. Moreover, Ertas et al. [26] showed that thymol and carvacrol help stimulate digestion by affecting pathogenic microorganisms in the gut of broilers, thereby increasing their food conversion rate and weight. The protection and reinforcement of the intestinal microbiome in broilers is critical for maintaining the overall health and optimal absorption of nutrients in these animals [27].

In this study, steam distillation was used to extract M. didyma EO, and GC-MS and GC-FID were used to analyze the composition of the EO. The antibacterial, antioxidant, and anti-inflammatory activities of M. didyma EO in vitro was assessed and results compared with the positive control Thymus vulgaris [24]. The objective of this study was to substitute standard antibiotics with $M$. didyma essential oil, although the main compounds responsible for the biological activities were identified and the effects of $M$. didyma $\mathrm{EO}$ on the growth performance, feed intake, and feed efficiency of mice and broilers were then evaluated.

\section{Results and Discussion}

M. didyma $\mathrm{EO}$, isolated by steam distillation, comprised mainly monoterpenes, which represented approximately $98 \%$ of the total, and some sesquiterpenes (1.24\%). M. didyma EO contained a high level of carvacrol $(49.03 \%)$. The other main compounds were $\gamma$-terpinene $(16.90 \%), p$-cymene $(7.60 \%)$, thymol $(6.17 \%)$, carvacrol methyl ether $(4.18 \%)$, 1-octen-3-ol $(3.07 \%), \alpha$-terpinene $(2.79 \%)$, myrcene $(2.33 \%), \alpha$-thujene $(1.39 \%)$, and limonene $(1.03 \%)(\mathrm{Ta}-$ ble 1). In total, 23 compounds were identified; all compounds had already been described in the scientific literature [28].

These compound concentrations showed some differences to previous research on EO extracts from $M$. didyma. In contrast to our observation of the highest compound levels being for carvacrol [29], analysis of EO from M. didyma cultivated in central Italy found thymol (59.3\%) to be the most dominant compound, followed by $p$-cymene (10.3\%), terpinolene (9.2\%), delta-3-carene (4.4\%), myrcene (3.7\%), and camphene (3.4\%). In 1967, Scora [30], using M. didyma EO from California, found $\gamma$-terpinene $(27.36 \%)$ as the most important compound, followed by d-limonene (12.93\%), 1,8 cineole (12.24\%), bornyl acetate $(7.74 \%)$, ketone (5.50\%), $\beta$-myrcene (4.88\%), linalyl acetate (5.06\%), $\alpha$-terpinol $(4.20 \%)$, and $\alpha$-pinene (3.10\%). Scora [30] did not observe thymol or carvacrol in their EO samples; 
they concluded that the oil from the inflorescences contained smaller amounts of terpene components. Finally, Carron et al. [31] analyzed several North American Monarda species. They found thymol and carvacrol to vary markedly between taxa, ranging from $8.5 \%$ thymol and $2.9 \%$ carvacrol in $M$. didyma (red bergamot variety) to $46.6 \%$ thymol and $19.2 \%$ carvacrol in M. fistulosa (Richters variety).

Table 1. Composition of M. didyma L. essential oil.

\begin{tabular}{|c|c|c|c|}
\hline \multicolumn{3}{|c|}{ Identified Compounds } & \multirow{2}{*}{$\begin{array}{c}\text { Relative } \\
\text { Concentration (\%) }\end{array}$} \\
\hline RI & Name & Identification ${ }^{1}$ & \\
\hline 930 & $\alpha$-thujene & MS, RI & 1.39 \\
\hline 938 & $\alpha$-pinene & MS, RI & 0.43 \\
\hline 976 & 1-octen-3-ol & MS, RI & 3.07 \\
\hline 992 & myrcene & MS, RI & 2.33 \\
\hline 1010 & $\alpha$-phellandrene & MS, RI & 0.36 \\
\hline 1016 & $\delta$-3-carene & MS, RI & 0.16 \\
\hline 1022 & $\alpha$-terpinene & MS, RI & 2.79 \\
\hline 1030 & $p$-cymene & MS, RI & 7.60 \\
\hline 1034 & limonene & MS, RI & 1.03 \\
\hline 1064 & $\gamma$-terpinene & MS, RI & 16.90 \\
\hline 1072 & cis-sabinene-hydrate & MS, RI & 0.25 \\
\hline 1094 & linalool & MS, RI & 0.15 \\
\hline 1174 & terpinen-4-ol & MS, RI & 0.11 \\
\hline 1185 & $\alpha$-terpineol & MS, RI & 0.79 \\
\hline 1232 & thymol methyl ether & MS, RI & 0.86 \\
\hline 1248 & carvacrol methyl ether & MS, RI & 4.18 \\
\hline 1294 & thymol & MS, RI & 6.17 \\
\hline 1306 & carvacrol & MS, RI & 49.03 \\
\hline 1435 & $\beta$-caryophyllene & MS, RI & 0.89 \\
\hline 1488 & germacrene D & MS, RI & 0.12 \\
\hline \multirow[t]{2}{*}{1511} & $\gamma$-cadinene & MS, RI & 0.23 \\
\hline & Total & & 98.84 \\
\hline
\end{tabular}

${ }^{1}$ MS: Identification by GC-MS; RI: Compounds were identified by comparison of GC retention indices relative to retention times of a series of $n$-alkanes $(\mathrm{C} 7-\mathrm{C} 36)$ and compared with literature data. Compounds $\leq 0.1 \%$ are not reported.

The high relative concentration of carvacrol and the presence of thymol suggested a promising antibacterial activity for $M$. didyma EO. Our observations of the antibacterial activity of $M$. didyma $\mathrm{EO}$ against $E$. coli $\left(\mathrm{MIC}=87 \mu \mathrm{g} \cdot \mathrm{mL}^{-1}\right.$ ) and against $S$. aureus $\left(\mathrm{MIC}=47 \mu \mathrm{g} \cdot \mathrm{mL}^{-1}\right.$ ) confirmed this antibacterial potential. The positive control T. vulgaris (Table S1) was also effective against E. coli $\left(\mathrm{MIC}=109 \mu \mathrm{g} \cdot \mathrm{mL}^{-1}\right)$ and S. aureus $\left(\mathrm{MIC}=111 \mu \mathrm{g} \cdot \mathrm{mL}^{-1}\right)$. The antibacterial activity of $M$. didyma EO versus E. coli and $S$. aureus was provided mainly by carvacrol, which had respective MIC values of $65 \mu \mathrm{g} \cdot \mathrm{mL}^{-1}$ and $36 \mu \mathrm{g} \cdot \mathrm{mL}^{-1}$, and thymol, which had respective MIC values of $110 \mu \mathrm{g} \cdot \mathrm{mL}^{-1}$ and $130 \mu \mathrm{g} \cdot \mathrm{mL}^{-1}$. M. didyma $\mathrm{EO}$ was also active versus C. perfringens, producing an MIC of $35 \mu \mathrm{g} \cdot \mathrm{mL}^{-1}$; this antibacterial activity versus $C$. perfringens was provided mainly by carvacrol that had an MIC of $18 \mu \mathrm{g} \cdot \mathrm{mL}^{-1}$, as well as thymol, having an MIC of $55 \mu \mathrm{g} \cdot \mathrm{mL}^{-1}$, and also limonene, which produced an MIC of $29 \mu \mathrm{g} \cdot \mathrm{mL}^{-1}$ (Table 2).

M. didyma $\mathrm{EO}$ also demonstrated anti-inflammatory activity. A concentration of $35 \mu \mathrm{g} \cdot \mathrm{mL}^{-1}$ inhibited fifty percent $\left(\mathrm{IC}_{50}\right)$ of NO induced by LPS in RAW 264.7 macrophages. Carvacrol $\left(\mathrm{IC}_{50}=22.6 \mu \mathrm{g} \cdot \mathrm{mL}^{-1}\right)$ and $p$-cymene $\left(\mathrm{IC}_{50}=25.5 \mu \mathrm{g} \cdot \mathrm{mL}^{-1}\right)$ appeared to be responsible, in part, for this activity. Furthermore, a cell-based assay with an $\mathrm{IC}_{50}$ of $4.6 \mu \mathrm{g} \cdot \mathrm{mL}^{-1}$ highlighted the EO antioxidant activity (Table 3). 
Table 2. Antibacterial activity of M. didyma and T. vulgaris (as positive control) essential oils and the main compounds against selected bacterial strains.

\begin{tabular}{cccc}
\hline \multirow{2}{*}{ Compounds } & \multicolumn{3}{c}{ Antibacterial Activity $\mathbf{M I C}\left(\boldsymbol{\mu g} \cdot \mathbf{m L}^{-\mathbf{1}}\right)$} \\
\cline { 2 - 4 } & $\boldsymbol{E}$. coli & S. aureus & C. perfringens \\
\hline T. vulgaris EO & $109 \pm 10$ & $111 \pm 7$ & $\mathrm{ND}$ \\
M. didyma EO & $87 \pm 8$ & $47 \pm 8$ & $35 \pm 4$ \\
Thymol & $110 \pm 7$ & $130 \pm 10$ & $55 \pm 3$ \\
Carvacrol & $65 \pm 5$ & $36 \pm 1$ & $18 \pm 1$ \\
$\alpha$-terpinene & $>200$ & $>200$ & $\mathrm{ND}$ \\
$\gamma$-terpinene & $>200$ & $>200$ & $\mathrm{ND}$ \\
p-cymene & $>200$ & $>200$ & $\mathrm{ND}$ \\
Limonene & $>200$ & $>200$ & $29 \pm 1$ \\
Myrcene & $>200$ & $>200$ & $\mathrm{ND}$ \\
\hline
\end{tabular}

ND: Not determined; data are representative of three different experiments; mean \pm standard deviation, $n=3$; MIC is defined as the lowest concentration inhibiting $95 \%$ of bacterial growth.

Table 3. Antioxidant and anti-inflammatory activity of $M$. didyma and T. vulgaris (as positive control) essential oils and the main compounds.

\begin{tabular}{|c|c|c|c|}
\hline \multirow{3}{*}{ Compounds } & \multicolumn{2}{|c|}{ Antioxidant } & \multirow{2}{*}{$\begin{array}{l}\text { Anti-Inflammatory } \\
\mathrm{IC}_{50}\left(\mu \mathrm{g} \cdot \mathrm{mL}^{-1}\right)\end{array}$} \\
\hline & Cell-Based Assay & ORAC & \\
\hline & $\mathrm{IC}_{50}\left(\mu \mathrm{g} \cdot \mathrm{mL}^{-1}\right)$ & $\mu \mathrm{mol}$ Trolox $\cdot \mathrm{mg}^{-1}$ & \\
\hline T. vulgaris EO & $11 \pm 9$ & $0.4 \pm 0.2$ & $64 \pm 6$ \\
\hline M. didyma $\mathrm{EO}$ & $4.6 \pm 0.3$ & $0.52 \pm 0.01$ & $35 \pm 4$ \\
\hline Thymol & $>200$ & $1.34 \pm 0.03$ & $>200$ \\
\hline Carvacrol & $54 \pm 9$ & $2.3 \pm 0.3$ & $22.6 \pm 0.2$ \\
\hline$\alpha$-terpinene & $3.4 \pm 0.2$ & $0.17 \pm 0.05$ & $>200$ \\
\hline$\gamma$-terpinene & ND & ND & $>200$ \\
\hline$p$-cymene & $>200$ & $0.02 \pm 0.01$ & $25.5 \pm 0.9$ \\
\hline Limonene & $6.2 \pm 0.5$ & $0.08 \pm 0.02$ & $22 \pm 7$ \\
\hline Myrcene & $92 \pm 4$ & $0.04 \pm 0.01$ & $>200$ \\
\hline Trolox & ND & $9 \pm 1$ & ND \\
\hline
\end{tabular}

The antibacterial and antioxidant activities of other members of the Lamiaceae family have been observed, principally for T. vulgaris and Origanum vulgare [32-36]; however, the biological activities of M. didyma are less well known. Fraternale et al. [22] used a DPPH and lipid peroxidation test to demonstrate the elevated antioxidant activity of M. didyma EO. Numerous studies have highlighted the antibacterial and antioxidant activities of EOs that possess high levels of phenolic compounds such as thymol, carvacrol, and eugenol $[9,24,25]$. Thymol and carvacrol appear to be particularly effective against Gram-negative bacteria, in part because these compounds act on the outer membrane, such as by provoking the release of lipopolycaccharides, increasing the permeability of the cytoplasmic membrane, and depolarizing the cytoplasmic membrane. Furthermore, hydroxyl groups are highly reactive and form hydrogen bonds with active sites of target enzymes, inactivating them, and consequently create a dysfunction or rupture of the cell membrane [25]. Similar to our study, Guimarães et al. [25] also observed high and rapid thymol and carvacrol activity against $E$. coli. Antioxidant and anti-inflammatory effects of the EO can produce a positive effect in the gastrointestinal tract.

Given that $M$. didyma EO demonstrated in vitro activities, the effectiveness of different concentrations of EO in the diet of mice on body weight gain (BW), feed intake (FI), and feed efficiency (FE) was assessed. A significant difference between the treatment groups and the negative control group for BW $(p<0.001)$, FI $(p<0.001)$, and FE $(p<0.001)$ was observed (Table 4). Supplementing the mouse diet with EO increased mouse BW throughout the experiment. EO concentrations of $0.1 \% \mathrm{M}$. didyma and $0.1 \%$ T. vulgaris markedly increased 
mouse BW (respectively 5.4\% and 9.4\%), compared with the untreated mice (average of $5.58 \mathrm{~g})$. EO dietary supplements decreased overall FI $(p<0.001)$ for all EO concentrations, especially for $M$. didyma $0.2 \%$ (145.24 g) and M. didyma $0.1 \%$ (141.58 g), compared to untreated mice (164.83 g). Finally, $M$. didyma $0.1 \%$ and $M$. didyma $0.2 \%$ produced the lowest FE ratios at 23.98 and 25.13, respectively. Therefore, diets supplemented with $T$. vulgaris $\mathrm{EO}$ and M. didyma $\mathrm{EO}$ at levels of $0.2 \%$ and $0.1 \%$ improved mouse BW and FE compared to the negative control.

Table 4. Comparison of mean body weight gain (g), feed intake (g), and feed efficiency of the mouse treatments.

\begin{tabular}{cccc}
\hline Treatments & $\begin{array}{c}\text { Body Weight Gain } \\
\text { (g) (BW) }\end{array}$ & Feed Intake (g) (FI) & $\begin{array}{c}\text { Feed Efficiency } \\
\text { (FI/BW) }\end{array}$ \\
\cline { 2 - 4 } & $\mathbf{0 - 8 0 ~ D a y s}$ & $\mathbf{0 - 8 0 ~ D a y s}$ & $\mathbf{0 - 8 0 ~ D a y s ~}$ \\
\hline Control & $5.58 \pm 1.01^{\mathrm{a}}$ & $164.83 \pm 1.55^{\mathrm{a}}$ & $29.55^{\mathrm{a}}$ \\
T. vulgaris $0.2 \%$ & $5.56 \pm 1.41^{\mathrm{b}}$ & $154.96 \pm 0.87^{\mathrm{b}}$ & $27.87^{\mathrm{b}}$ \\
T. vulgaris $0.1 \%$ & $6.16 \pm 1.44^{\mathrm{b}}$ & $163.39 \pm 14.21^{\mathrm{c}}$ & $26.54^{\mathrm{c}}$ \\
M. didyma $0.2 \%$ & $5.78 \pm 1.40^{\mathrm{c}}$ & $145.24 \pm 7.81^{\mathrm{c}}$ & $25.13^{\mathrm{c}}$ \\
M. didyma $0.1 \%$ & $5.90 \pm 1.17^{\mathrm{c}}$ & $141.58 \pm 2.78^{\mathrm{c}}$ & $23.98^{\mathrm{c}}$ \\
\hline
\end{tabular}

$\overline{\text { Values with different letters in the same column }(\mathrm{a}-\mathrm{c}) \text { differ significantly (two-way analysis of variance, } p<0.05)}$.

No studies have yet tested EO diet supplements in mice; however, Denli et al. [20] observed that T. vulgaris EO caused BW gain and improved FE for quail. Platel et al. [37] concluded that adding various spices in food enhanced either enzyme activity related to digestion or increased the secretion of bile. Yang et al. [38] observed that EO supplementation during the growth period increased lipase, trypsin, and chymotrypsin activities significantly. EO also increased the fecal digestibility of dry matter and the digestibility of ether extract, fiber, fat, ash, and protein [18]. The improvement of BW and FE in our study of mice was attributed to these processes.

When $M$. didyma $\mathrm{EO}$ was added to the diet of male broilers, during a growth period of 36 days, the treated broilers attained a BW of $2.65 \mathrm{~kg}$ with an average of $4.46 \mathrm{~kg}$ of FI by the animals. Control broilers with standard antibiotics weighed $2.58 \mathrm{~kg}$ after an average FI of $4.51 \mathrm{~kg}$. Broilers fed with the EO-supplemented diet therefore showed a BW increase of $2.64 \%$ compared to control animals fed using standard antibiotics (Table 5). A significant difference was observed for BW between the control and M. didyma EO broilers in the first 10 days (268.5 g and $279 \mathrm{~g}$, respectively). During the growth and finisher phases, broilers fed with the EO diet were significantly heavier than the control broilers with antibiotics and followed the same growth curve (Figure S1).

Table 5. Comparison of mean body weight gain $(\mathrm{g})$, feed intake $(\mathrm{g})$, and feed efficiency of the broiler treatments.

\begin{tabular}{|c|c|c|c|c|c|c|}
\hline \multirow{2}{*}{ Treatments } & \multicolumn{2}{|c|}{ Body Weight Gain (g) (BW) } & \multicolumn{2}{|c|}{ Feed Intake (g) (FI) } & \multicolumn{2}{|c|}{ Feed Efficiency (FI/BW) } \\
\hline & 0-10 Days & 0-36 Days & 0-10 Days & 0-36 Days & 0-10 Days & 0-36 Days \\
\hline Antibiotics suppl. & $269 \pm 7^{a}$ & $2578 \pm 117^{a}$ & $384.71^{¥}$ & $4514.25^{¥}$ & $1.43^{¥}$ & $1.75^{¥}$ \\
\hline M. didyma suppl. & $279 \pm 8^{b}$ & $2652 \pm 121^{b}$ & $360.36^{¥}$ & $4455.81^{¥}$ & $1.29^{¥}$ & $1.68^{¥}$ \\
\hline
\end{tabular}

$¥$ Values are available only at the end of the experiment; values in the same column with different letters (a-b) differ significantly (two-way analysis of variance, $p<0.05)$.

Existing studies identify four different mechanisms that are important for EO actionsensorial, metabolic, antioxidant, and antibacterial activities [13]. Hashemipour et al. [39] demonstrated that supplementing a broiler diet with $100 \mathrm{mg} / \mathrm{kg}$ and $200 \mathrm{mg} / \mathrm{kg}$ of thymol and carvacrol, respectively, produced no effect on FI, but significantly increased BW gain and improved the feed conversion ratio. Antibiotics in animals improve the BW by $5-6 \%$ and the FE by $3-4 \%$, with the most pronounced effects observed in young animals [6]. Khattak et al. [15], supplementing the diets of broilers with a natural blend of EO (including 
thyme and oregano), observed no significant difference in growth performance during the starter period. Although higher mortality rates could be expected in the EO test group due to the lack of antibiotic use, Khattak et al. [15] found no significant difference between the mortality of broilers having the EO-supplemented diet and that of the control broilers.

\section{Materials and Methods}

\subsection{Chemicals}

Standard compounds used for GC analyses and biological testing were obtained from Sigma-Aldrich (St. Louis, MO, USA); the compounds included thymol, carvacrol, $\gamma$-terpinene, $p$-cymene, $\alpha$-terpinene, myrcene, and limonene.

\subsection{Plant Material and Extraction of Essential Oils}

M. didyma L. EO was extracted by steam distillation for three hours from freshly harvested aerial parts (refractive index $=1.4977$; density $=0.939 \mathrm{~g} \cdot \mathrm{mL}^{-1}$; yield $(\%)=0.49$ ). The plant came from Saint-Fulgence, Québec and was harvested at the beginning of August (Voucher QFA0625784). Thymus vulgaris L. EO (refractive index $=1.4797$; density $=0.923 \mathrm{~g} \cdot \mathrm{mL}^{-1}$ ) was purchased from Aliksir (Grondines, QC, Canada). The EO yield from extraction depended on the total amount of the raw material. The $\mathrm{EO}$ was then stored in the dark at a temperature of $4{ }^{\circ} \mathrm{C}$ until needed.

\subsection{GC-FID and GC-MS Analysis}

All chromatographic analyses were run on an Agilent 6890N GC (Agilent Technologies, Santa Clara, CA, USA) equipped with a non-polar DB-5 column and a polar SolGel-Wax column $(30 \mathrm{~m} \times 0.25 \mathrm{~mm} \times 0.25 \mathrm{~mm})$ as well as two flame ionization detectors (FIDs) (Agilent Technologies, Santa Clara, CA, USA). The oils were injected in an undiluted $(0.1 \mu \mathrm{L}$ injection volume, split 1:235) and undried state (Figure S2). The temperature program began at $40^{\circ} \mathrm{C}$ for $2 \mathrm{~min}$, then rose $2{ }^{\circ} \mathrm{C} \cdot \mathrm{min}^{-1}$ up to $210^{\circ} \mathrm{C}$. The temperature was then held at $210^{\circ} \mathrm{C}$ for $13 \mathrm{~min}$. Samples were also injected into an Agilent 7890A GC (Agilent Technologies, Santa Clara, CA, USA) coupled to an Agilent 5975C InertXL EI/CI mass spectrometer (MS) equipped with a DB-5MS column using the same temperature program as above and a split of 1:1000. Compounds were identified from their retention indexes as calculated from even-numbered C7 to C36 alkane standards and from Wiley 6N, MS databases (NIST08) and standard injection when available (LASEVE, UQAC, Chicoutimi, QC, Canada). Quantification was derived from the FID response on the DB-5 column without any correction factor.

\subsection{In Vitro Activity of Essential Oil \\ 3.4.1. Cell Culture}

Healthy human skin fibroblasts WS1 (ATCC CRL-1502) and the murine macrophage RAW 264.7 (ATCC TIB-71) were obtained from the American Type Culture Collection (Manassas, VA, USA). Cells were grown in a humidified atmosphere at $37{ }^{\circ} \mathrm{C}$ in $5 \% \mathrm{CO}_{2}$, in Dulbecco's minimum essential medium supplemented with $10 \%$ fetal calf serum (Hyclone, Logan, UT, USA), $1 \times$ solution of sodium pyruvate, $1 \times$ vitamins, $1 \times$ non-essential amino acids, $100 \mathrm{IU}$ of penicillin, and $100 \mu \mathrm{g} \cdot \mathrm{mL}^{-1}$ streptomycin (Cellgro ${ }^{\circledR}$, Mediatech, Manassas, VA, USA).

\subsubsection{Bacterial Strains}

The in vitro antimicrobial activity of $M$. didyma $\mathrm{EO}$ was tested against Gram-negative Escherichia coli (ATCC 25922), Gram-positive Staphylococcus aureus (ATCC 25923), and Grampositive Clostridium perfringens provided by the Chicoutimi Hospital, Saguenay, Canada. Bacteria were grown in a humidified atmosphere at $37^{\circ} \mathrm{C}$. 


\subsubsection{Culture Methods}

Bacteria were stored at $-80^{\circ} \mathrm{C}$ until use. For culturing the bacteria, all bacteria were placed in a nutrient broth base (Difco) for $16-18 \mathrm{~h}$ at $37^{\circ} \mathrm{C}$; C. perfringens was grown in an anaerobic vial. The cellular density of the inoculum was measured via optical density at $600 \mathrm{~nm}$ for E. coli [40], $660 \mathrm{~nm}$ for S. aureus [41], and $450 \mathrm{~nm}$ for C. perfringens using a Multiskan ${ }^{\mathrm{TM}}$ GO Spectrophotometer (Thermo Fisher Scientific). The inoculum was rediluted in the nutrient broth to obtain the required bacterial concentration.

\subsubsection{Measurement of Anti-Inflammatory Activity}

The inhibition of nitric oxide (NO) production by M. didyma $\mathrm{EO}$ and compounds was evaluated following Legault et al. [42]. Control L-NAME was used as a positive control. The murine macrophage RAW 264.7 cells were incubated with EO or dissolved compounds in DMSO, then stimulated using $100 \mathrm{ng} \cdot \mathrm{mL}^{-1} \mathrm{LPS}$ and incubated at $37^{\circ} \mathrm{C}$. After $24 \mathrm{~h}$, the cellfree supernatant was collected and the NO concentration immediately determined using the Griess reaction. The absorbance was read at $540 \mathrm{~nm}$ using an automated Varioskan Ascent plate reader, and the presence of nitrite was quantified by comparing with a $\mathrm{NaNO}^{2}$ standard curve, and $\mathrm{IC}_{50}$ expressed $50 \%$ of $\mathrm{NO}$ inhibition.

\subsubsection{Evaluation of Antioxidant Activity Using Cell-Based Assays}

The antioxidant activity was evaluated using the DCFH-DA assay as described by Girard-Lalancette et al. [43]. Human skin fibroblasts WS1 were incubated for $1 \mathrm{~h}$ with a growing concentration of EO or dissolved compounds in DMSO. One hundred microliters of $200 \mu \mathrm{M}$ tert-butylhydroperoxide was then added and fluorescence immediately measured, and again after $90 \mathrm{~min}$. Measurements were made on an automated plate reader (Fluoroskan Ascent FL, Labsystems, Milford, MA, USA) using an excitation wavelength of $485 \mathrm{~nm}$ and an emission wavelength of $530 \mathrm{~nm}$. Antioxidant activity was expressed as the concentration of extract inhibiting $50 \%\left(\mathrm{IC}_{50}\right)$ of DCFH oxidation.

\subsubsection{Evaluation of Antioxidant Activity Using ORAC}

The method described by Ou et al. [44] with some modifications was followed. Briefly, the ORAC assay was carried out in black 384-well microplates (Nunc) on a Fluoroskan Ascent FL ${ }^{\mathrm{TM}}$ plate reader (Labsystems) equipped with an automated injector. Four concentrations of Trolox (the control standard) $(1.56,3.13,6.25$, and $12.5 \mu \mathrm{M})$ were used in quadruplicate, and a gradient of 16 concentrations of the samples (compounds dissolved in DMSO or pure EO) was prepared without replication. The experiment was conducted at $37.5{ }^{\circ} \mathrm{C}$ and in a pH 7.4 phosphate buffer with a blank sample run in parallel. The fluorimeter was programmed to record the fluorescence $(\lambda$ ex.: $485 \mathrm{~nm} / \mathrm{em}: 530 \mathrm{~nm})$ of fluorescein every minute after the addition of $375 \mathrm{mM}$ of 2,2'-azobis(2-amidinopropane) dihydrochloride (AAPH), for a total of $60 \mathrm{~min}$. The final values were calculated using the net area under the curves of the sample concentrations for which a decrease of at least $95 \%$ of fluorescence was observed at $60 \mathrm{~min}$. ORAC values were expressed in micromoles of Trolox equivalents (TE) per milligram $\left(\mu \mathrm{mol} \mathrm{TE} \cdot \mathrm{mL}^{-1}\right)$.

\subsubsection{Evaluation of Antibacterial Activity}

The antibacterial activity of $M$. didyma EO and compounds was tested using the antibacterial hydrophobic assay as described by Côté et al. [45]. Briefly, after micro-organisms passed $16-18 \mathrm{~h}$ at $37^{\circ} \mathrm{C}$ in a nutrient broth base (Difco), $20 \mu \mathrm{L}$ methanol containing growing concentrations of EO and compounds ( 3.1 to $200 \mu \mathrm{g} \cdot \mathrm{mL}^{-1}$ ) was transferred onto nutrient agar in 96-well plates. Bacterial strains having a concentration of $2.5 \times 10^{5}$ colony-forming units (CFU) were then added per $\mathrm{mL}$ of nutrient broth. Bacterial suspension without treatment was used as a negative control, and bacterial suspension plus solvent were tested in parallel to demonstrate the absence of solvent toxicity. The blank consisted of a culture medium only and was subtracted from all subsequent measurements of each well. The 96-well plates were then incubated at $37^{\circ} \mathrm{C}$ for $5 \mathrm{~h}$ to foster bacterial growth. One hundred 
microliters of resazurin sodium salt solution with a concentration of $50 \mu \mathrm{g} \cdot \mathrm{mL}^{-1}$ (Sigma R-2127, St-Louis, MO, USA) was then added to each well. Fluorescence was read on an automated Fluoroskan Ascent FLTM plate reader (Labsystems, Milford, MA, USA) after $2 \mathrm{~h}$ for S. aureus and $3 \mathrm{~h}$ for E. coli and C. perfringens. The MIC was determined as the lowest concentration resulting in $95 \%$ inhibition of bacterial growth.

\subsection{Experimental Design in Mice}

Mice were fed with a mouse diet specifically designed to support the growth and maintenance of animals (LabDiet $5015 ; 20 \%$ protein, $25 \%$ fat, 55\% carbohydrate). The treatments were prepared by adding concentrations of M. didyma and T. vulgaris (used as the positive control) $\mathrm{EO}$ at $0.2 \%$ and $0.1 \%$, to the original control diet. The food containing EO was prepared every week to ensure its freshness and quality. Our experiment was assessed for its ethical acceptability and was approved by the APC (Animal Protection Committee of UQAC, Université du Québec à Chicoutimi). Mice were housed in cages in an environmentally controlled room, having $12 \mathrm{~h}$ of darkness followed by a period of $12 \mathrm{~h}$ of light during the entire run of the experiment. Each cage was provided with a single feed and water system to provide ad libitum access. Fifty (50) mice (five-week-old Charles River males) were placed in cages; each cage contained five randomly selected mice (two replicates). Each cage was assigned to one of five dietary treatments (four EO treatments and one negative control), giving a total of ten (10) experimental cages. The study was completed after 80 days of treatment. BW was measured twice a week and average FI determined on a weekly basis. For each week, the FE per cage was calculated based on the average BW and FI per mouse.

\subsection{Experimental Design for Broilers}

Male broilers $(n=8216)$ were divided into four treatment groups: two control ( $n=2054$ each) and two treatment $(n=2054$ each). The broilers were installed in an insulated room with facilities for control temperature, light, and humidity according to industry standards. Broilers were fed with the Nutrinor standard diet for poultry. The feeding program consisted of a starter (1-10 d), growth (11-20 d), and finisher (21-35 d) diet given to each broiler ad libitum. The treatment group received $0.5 \% \mathrm{M}$. didyma $\mathrm{EO}$ in the starter diet, $0.1 \% \mathrm{EO}$ in the growth diet, and $0.05 \% \mathrm{EO}$ in the finisher diet. The control group received standard antibiotics: Maxiban ${ }^{\mathrm{TM}}(0.5 \mathrm{~kg} /$ metric tons (MT) $)$ and Tylosine $(0.25 \mathrm{~kg} / \mathrm{MT})$. Broilers were weighed daily using an automatic balance installed in the hen house. Mortality was recorded daily and total FI was determined at the end of the experiment.

\subsection{Statistical Analysis}

Analysis of variance (ANOVA) was run on all our collected data using the statistical analysis system Sigma STAT. If appropriate, multiple comparison procedures were performed with the Holm-Sidak method. Statements of statistical significance are based on $p<0.05$.

\section{Conclusions}

Our results confirmed the in vitro antibacterial, antioxidant, and anti-inflammatory activities of $M$. didyma EO. A diet supplemented with $M$. didyma EO significantly increased mouse BW and suggested good biological activity in broilers. EO has good potential as an alternative to synthetic antibiotics used in animal nutrition. Future research must explore M. didyma EO in vivo antibacterial activity against E. coli and C. perfringens. Nonetheless, the different dosages of M. didyma EO in the starter, growth, and finisher phases of the broiler diets remain to be tested to determine the optimal concentrations. 
Supplementary Materials: The following are available online, Figure S1: Body weight gain for M. didyma essential oil and antibiotics groups for day 0-36. Data represent de mean of the two groups, Figure S2: Chromatograms with GC-FID obtain for M. didyma essential oil. Table S1: Composition of Thymus vulgaris L. essential oil.

Author Contributions: Conceptualization, J.L. and H.C.; methodology, H.C.; result, H.C., A.S.-G. and J.L.; writing—original draft preparation, H.C.; writing—review and editing, J.L. and A.P.; supervision, J.L. and A.P.; project administration, J.L. and A.P. All authors have read and agreed to the published version of the manuscript.

Funding: This work was supported by funds from the Fonds de recherche du Québec, Nature et technologies (FRQNT), grant 164529, and from Nutrinor.

Institutional Review Board Statement: Not applicable.

Informed Consent Statement: Not applicable.

Data Availability Statement: The data presented in this study are available in Supplementary Material.

Acknowledgments: The authors are grateful to Catherine Dussault and Karl Girard-Lalancette for their help and suggestions with using the biological assay; Claire Fournier and Joanie Tremblay are thanked for their help with the mice experiments, and we thank Chantale Bélanger from Nutrinor for her help with the broiler assay.

Conflicts of Interest: The authors declare no conflict of interest.

\section{References}

1. Feighner, S.D.; Dashkevicz, M.P. Subtherapeutic levels of antibiotics in poultry feeds and their effects on weight gain, feed efficiency, and bacterial cholyltaurine hydrolase activity. Appl. Environ. Microbiol. 1987, 53, 331-336. [CrossRef]

2. Graham, J.P.; Boland, J.J.; Silbergeld, E. Growth promoting antibiotics in food animal production: An economic analysis. Public Health Rep. 2007, 122, 79-87. [CrossRef]

3. Dibner, J.J.; Richards, J.D. Antibiotic growth promoters in agriculture: History and mode of action. Poult. Sci. 2005, 84, 634-643. [CrossRef] [PubMed]

4. Srivastava, M.K. Antibiotic growth-promoters in food animals. Pharma Times 2010, 42, 17-21.

5. Weber, E.M.; Luther, H.G.; Reynolds, W.M. Antibiotics as animal-growth stimulants. Bull. World Health Organ. 1952, 6, 149-161. [PubMed]

6. Diarra, M.S.; Malouin, F. Antibiotics in Canadian poultry productions and anticipated alternatives. Front. Microbiol. 2014, 5, 282. [CrossRef]

7. Nakatani, N. Phenolic antioxidants from herbs and spices. BioFactors 2000, 13, 141-146. [CrossRef]

8. Craig, W.J. Health-promoting properties of common herbs. Am. J. Clin. Nutr. 1999, 70, 491S-499S. [CrossRef]

9. Burt, S. Essential oils: Their antibacterial properties and potential applications in foods-A review. Int. J. Food Microbiol. 2004, 94, 223-253. [CrossRef]

10. Diaz-Sanchez, S.; D'Souza, D.; Biswas, D.; Hanning, I. Botanical alternatives to antibiotics for use in organic poultry production. Poult. Sci. 2015, 94, 1419-1430. [CrossRef]

11. William, P.; Losa, R. The use of essential oils and their compounds in poultry nutrition. World Poult. 2001, 17, 14-15.

12. Lee, K.-W. Essential oils in broiler nutrition. Int. J. Poult. Sci. 2002, 3, 738-752.

13. Brenes, A.; Roura, E. Essential oils in poultry nutrition: Main effects and modes of action. Anim. Feed Sci. Technol. 2010, 158, 1-14. [CrossRef]

14. Hashemi, S.R.; Davoodi, H. Herbal plants and their derivatives as growth and health promoters in animal nutrition. Vet. Res. Commun. 2011, 35, 169-180. [CrossRef]

15. Khattak, F.; Ronchi, A.; Castelli, P.; Sparks, N. Effects of natural blend of essential oil on growth performance, blood biochemistry, cecal morphology, and carcass quality of broiler chickens. Poult. Sci. 2014, 93, 132-137. [CrossRef] [PubMed]

16. Zeng, Z.; Zhang, S.; Wang, H.; Piao, X. Essential oil and aromatic plants as feed additives in non-ruminant nutrition: A review. J. Anim. Sci. Biotechnol. 2015, 6, 1-7. [CrossRef] [PubMed]

17. Zhang, K.Y.; Yan, F.; Keen, C.A.; Waldroup, P.W. Evaluation of microencapsulated essential oils and organic acids in diets for broiler chickens. Int. J. Poult. Sci. 2005, 4, 612-619.

18. Hernández, F.; Madrid, J.; García, V.; Orengo, J.; Megías, M.D. Influence of two plant extracts on broilers performance, digestibility, and digestive organ size. Poult. Sci. 2004, 83, 169-174. [CrossRef]

19. Cross, D.E.; McDevitt, R.M.; Hillman, K.; Acamovic, T. The effect of herbs and their associated essential oils on performance, dietary digestibility and gut microflora in chickens from 7 to 28 days of age. Br. Poult. Sci. 2007, 48, 496-506. [CrossRef] [PubMed]

20. Denli, M.; Okan, F.; Uluocak, A.N. Effect of dietary supplementation of herb essential oils on the growth performance, carcass and intestinal characteristics of quail (Coturnix coturnix japonica). S. Afr. J. Anim. Sci. 2004, 34, 174-179. 
21. Hamel, P.B.; Chiltoskey, M.U. Cherokee Plants and Their Uses-A 400 Year History; Sylva, N.C., Ed.; Herald Publishing Co.: Tecumseh, MI, USA, 1975; 72p.

22. Fraternale, D.; Giamperi, L.; Bucchini, A.; Ricci, D.; Epifano, F.; Burini, G.; Curini, M. Chemical composition, antifungal and in vitro antioxidant properties of Monarda didyma L. essential oil. J. Essent. Oil Res. 2006, 18, 581-585. [CrossRef]

23. Ben Arfa, A.; Combes, S.; Preziosi-Belloy, L.; Gontard, N.; Chalier, P. Antimicrobial activity of carvacrol related to its chemical structure. Lett. Appl. Microbiol. 2006, 43, 149-154. [CrossRef] [PubMed]

24. Mancini, E.; Senatore, F.; Del Monte, D.; De Martino, L.; Grulova, D.; Scognamiglio, M.; Snoussi, M.; De Feo, V. Studies on chemical composition, antimicrobial and antioxidant activities of five Thymus vulgaris L. essential oils. Molecules 2015, 20, 12016-12028. [CrossRef]

25. Guimarães, A.C.; Meireles, L.M.; Lemos, M.F.; Guimarães, M.C.C.; Endringer, D.C.; Fronza, M.; Scherer, R. Antibacterial activity of terpenes and terpenoids present in essential oils. Molecules 2019, 24, 2471. [CrossRef] [PubMed]

26. Ertas, O.N.; Güler, T.; Çiftçi, M.; Dalkilic, B.; Simsek, Ü.G. The effect of an essential oil mix derived from oregano, clove and anise on broiler performance. Int. J. Poult. Sci. 2005, 4, 879-884.

27. Danzeisen, J.L.; Kim, H.B.; Isaacson, R.E.; Tu, Z.J.; Johnson, T.J. Modulations of the chicken cecal microbiome and metagenome in response to anticoccidial and growth promoter treatment. PLoS ONE 2011, 6, e27949. [CrossRef]

28. Adams, R.P. Identification of Essential Oil Components by Gas Chromatography/Mass Spectrometry, 4th ed.; Allured Publishing Corporation: Carol Stream, IL, USA, 2007.

29. Ricci, D.; Epifano, F.; Fraternale, D. The essential oil of Monarda didyma L. (Lamiaceae) exerts phytotoxic activity in vitro against various weed seeds. Molecules 2017, 22, 222. [CrossRef]

30. Scora, R.W. Study of the essential leaf oils of the genus Monarda (Labiatae). Am. J. Bot. 1967, 54, 446-452. [CrossRef]

31. Carron, C.A.; Jaunin, L.; Grogg, A.F. La monarde fistuleuse, source naturelle de geraniol, d'acide rosmarinique et de flavonoides. Rev. Suisse Vitic. Arboric. Hortic. 2007, 39, 229-235.

32. Dorman, H.J.; Deans, S.G. Antimicrobial agents from plants: Antibacterial activity of plant volatile oils. J. Appl. Microbiol. 2000, 88, 308-316. [CrossRef]

33. Saini, R.; Davis, S.; Dudley-Cash, W. Oregano essential oil reduces necrotic enteritis in broilers. In Proceedings of the Fifty-Second Western Poultry Disease Conference, Sacramento, CA, USA, 8-11 March 2003; pp. 95-98.

34. Sivropoulou, A.; Papanikolaou, E.; Nikolapu, C.; Kokkini, S.; Lanaras, T.; Arsenakis, M. Antimicrobial and cytotoxic activities of Origanum essential oils. J. Agric. Food Chem. 1996, 44, 1202-1205. [CrossRef]

35. Rota, M.C.; Herrera, A.; Martínez, R.M.; Sotomayor, J.A.; Jordán, M.J. Antimicrobial activity and chemical composition of Thymus vulgaris, Thymus zygis and Thymus hyemalis essential oils. Food Control 2008, 19, 681-687. [CrossRef]

36. Ji, K.L.; Gan, X.Q.; Xu, Y.K.; Li, X.F.; Guo, J.; Dahab, M.M.; Zhang, P. Protective effect of the essential oil of Zanthoxylum myriacanthum var. pubescens against dextran sulfate sodium-induced intestinal inflammation in mice. Phytomedicine 2016, 23, 883-890. [CrossRef]

37. Platel, K.; Srinivasan, K. Studies on the influence of dietary spices on food transit time in experimental rats. Nutr. Res. 2001, 21, 1309-1314. [CrossRef]

38. Yang, X.; Xin, H.; Yang, C.; Yang, X. Impact of essential oils and organic acids on the growth performance, digestive functions and immunity of broiler chickens. Anim. Nutr. 2018, 4, 388-393. [CrossRef]

39. Hashemipour, H.; Kermanshahi, H.; Golian, A.; Khaksar, V. Effects of carboxy methyl cellulose and thymol + carvacrol on performance, digesta viscosity and some blood metabolites of broilers. J. Anim. Physiol. Anim. Nutr. 2013, 98, 672-679. [CrossRef]

40. Pal, S.; Tak, Y.K.; Song, J.M. Does the antibacterial activity of silver nanoparticles depend on the shape of the nanoparticle? A study of the Gram-negative bacterium Escherichia coli. Appl. Environ. Microbiol. 2007, 73, 1712-1720. [CrossRef] [PubMed]

41. Kaatz, G.W.; Seo, S.M.; Brien, L.O.; Foster, T.J.; Wahiduzzaman, M. Evidence for the existence of a multidrug efflux transporter distinct from NorA in Staphylococcus aureus. Antimicrob. Agents Chemother. 2000, 44, 1404-1406. [CrossRef] [PubMed]

42. Legault, J.; Girard-Lalancette, K.; Grenon, C.; Dussault, C.; Pichette, A. Antioxidant activity, inhibition of nitric oxide overproduction, and in vitro antiproliferative effect of maple sap and syrup from Acer saccharum. J. Med. Food 2010, 13, 460-468. [CrossRef] [PubMed]

43. Girard-Lalancette, K.; Pichette, A.; Legault, J. Sensitive cell-based assay using DCFH oxidation for the determination of proand antioxidant properties of compounds and mixtures: Analysis of fruit and vegetable juices. Food Chem. 2009, 115, 720-726. [CrossRef]

44. Ou, B.; Hampsch-Woodill, M.; Prior, R.L. Development and validation of an improved oxygen radical absorbance capacity assay using fluorescein as the fluorescent probe. J. Agric. Food Chem. 2001, 49, 4619-4626. [CrossRef] [PubMed]

45. Côté, H.; Boucher, M.A.; Pichette, A.; Roger, B.; Legault, J. New antibacterial hydrophobic assay reveals Abies balsamea oleoresin activity against Staphylococcus aureus and MRSA. J. Ethnopharmacol. 2016, 194, 684-689. [CrossRef] [PubMed] 